\title{
CIDEM's femicide archive and the process of gendered legal change in Bolivia
}

\author{
Xandra Miguel-Lorenzo
}

\begin{abstract}
This article analyses a spectacle, a wrestling match, that brings out the problem of violence against women and the role of activist organisations such as the Centro de Información y Desarrollo de la Mujer (CIDEM) to raise awareness among people and to influence the Bolivian state to change the gender of the law. In effect, it considers CIDEM's vigilant role, by visualising cases of femicides in partnership with the press, is translated in wrestling matches. The article considers one such wrestling match I witnessed in El Alto, Bolivia, and argues that CIDEM's vigilant role extends to overlooking and complementing the vigilant roles of the state and customary legal systems in El Alto that are unable to prevent femicides: women being killed by men because of their gender.
\end{abstract}

Keywords: femicide, feminism, gender, legal change, press, violence, urban anthropology

In the wrestling ring at the Multipurpose Arena of El Alto, ${ }^{1}$ Bolivia, indigenous Aymara women known as cholitas ${ }^{2}$ fight women and men. In 2010, a cholita wearing her characteristic pollera (a full, layered skirt) with a matching bright yellow jumper and dainty shoes, and her hair arranged in two long braids, fought a man in a military outfit 'identifiable' as a colonel. The cholita was mostly beaten up by the colonel. When she seemed to have lost the fight, she 'stood up' to overpower the colonel, equalising the power of the genders in this context. The cholita walked away from the wrestling ring, concluding the spectacle before her male opponent recovered 'consciousness' so he could not retaliate. The spectacle, supposedly harmless for the wrestlers and entertaining for Bolivian spectators and foreign tourists, bore a strong resemblance to national newspaper articles on men beating and murdering women, particularly cholitas living in the city of El Alto. A journalistic genre of 
violence that was extended in these matches between cholitas and men was even more familiar at the feminist women's organisation called the Centro de Información y Desarrollo de la Mujer (Women's Information and Development Center-CIDEM) ${ }^{3}$ where I volunteered as a researcher-activist for five months. CIDEM, a feminist women's organisation, while providing 'integral psycho-socio-legal support services' to abused women, also led a national campaign (2008-2013) to modify the penal code criminalising femicide. ${ }^{4}$

This article considers how the staged violent match between the cholita and the colonel relates first to the problem of urban security, in El Alto and in La Paz more widely, particularly the problem of violence against women in an urban setting. This violence is regarded as widespread according to articles compiling CIDEM's femicide archive. CIDEM recorded 98 femicides in 2009 and 89 in 2010 (Marca Paco et al. 2015: 21). Second, the match, while performing the gendered dynamics of violence, is related to the need for organisations such as CIDEM to be a 'constant vigilant' (Marca Paco et al. 2015: 23). CIDEM, in effect, saw itself as conducting essential vigilance to document, highlight and campaign against gendered violence. The visualisation of violence against women on public display through the wrestling match was a strong marker of the dynamics of gendered violence and urban femicides. I consider a body of photographic images I took to describe the wrestling bout between the cholita and the colonel. These images were seen, and so are analysed, from a Melanesian point of view. This article offers a decomposition of these images by unpacking the social relations that compose them and are their cause (Strathern 1992: 246). This relates to the journalistic articles and related images found in CIDEM's femicide archive, and its ultimate cause, the actual killings of Bolivian women.

Nell Haynes (2015) argues the 'fighting cholitas' act as icons both of indigenous women caricatured as violent and unruly, and of indigenous protest against colonial powers and unfair social policies. She argues the figure of the cholita in the wrestling ring undoes the political power that indigenous violence might have in protest settings by converting it into spectacle. Contrary to this, however, she posits that women who are wrestlers employ the image of the cholita as symbols to increase their social status, earning money and fame through acting, and this is 'strategic essentialism' (Haynes 2013: 434). Furthermore, Haynes says her research participants, women performing as wrestling cholitas, associate the figure of the fighting cholita with strength, enabling an image of Bolivian women who are not subjected to men's violence that promotes gender equality (443). This new female model, 
the performers argued, challenges the gender normative model that naturalises women as being victims of men's violence (Haynes 2013). Drawing on Haynes's analysis, I further posit the image of wrestling cholitas when fighting men indexes Bolivian women's organisations' discourses against gender violence and pro-gender equality preceding the change of the law criminalising femicides.

The wrestling bout between the cholita and the colonel in the Ceja, the commercial heart of El Alto, furthermore served as a popular visual moral anchorage for the intersecting current legal debates on urban security, including considerations on the relation between customary and state legal systems. In considering these dynamics and the larger setting of gendered violence, the article first examines the wrestling match as a consecutive series of images that are later decomposed or linked to national journal articles. It argues the images capturing the wrestling match recall, in the first instance, two conflicting legal systems, the 'indigenous' and 'the postcolonial'. In the second instance, it reproduces clichéd descriptions available in the mass media of violence against women and, particularly, of femicides, thus becoming a spectacle to be documented as part of the vigilance against violence. The article considers the limits of the 'vigilant' roles of the state and indigenous legal systems as supplemented by CIDEM's vigilance over crimes of gender violence to bring about its strategy to combat femicides, and to change the gender of the law. The analysis of CIDEM's 'vigilant' role illuminates the possibilities and limits of this strategy.

Considering the wrestling match here analysed and its linkages to CIDEM's archive of national newspaper articles on femicides, this article argues for popular implicit ways of knowing about femicides, and for the subjective experience of legal transformation, as affective performative 'embodied epistemology' (Madison Soyini 2010: 6-7). The wrestling match combines 'full body engagement with critical reflexivity' (7) in the process of reimagining and building a new democratic reality. It captures a moment of change that is not ignited by a radical event in the implementation of a new legal framework. Prompted by mass media and CIDEM's vigilance and visualisation work, critical ideas about femicides were projected onto the public and turned into pop culture, to be carefully observed and thoughtfully considered. Making it accessible to the public via a popular spectacle, to some extent, delinked from CIDEM's feminist ethos returned the question of violence against women and femicide to a matter of gender equality. The wrestling match here considered, rather than merely reproducing discriminatory and violent gender dynamics or social commentary on 
gender (Haynes 2013: 433), is understood as a 'radical act' of activism (Madison Soyini 2010: 18), and the wrestlers are advocates against femicides by proxy because they enable women's struggles to be heard by exposing the 'root' of the problem (Ibid). Here the 'internal essence of gender' is both maintained and subverted through sustained sets of acts (Butler 1999).

\section{The journey to the wrestling ring}

My attendance at the wrestling show inspired by a friend and colleague at CIDEM became incorporated into my understanding of the overall work as an activist-researcher at CIDEM's archival centre in La Paz. ${ }^{5}$ I had expected the wrestling match to be comical with the typical men in leotards and American masks, or the popular fighting cholitas, two Aymara women fighting each other (Haynes 2015). Nonetheless, this expectation was challenged when at the show a wrestler cholita and a wrestler 'colonel' started a fight. This immediately identified that this rehearsed mock fight produced and drew on current cultural scripts of violence against women made available in the news and available in CIDEM's femicide archive and its newsletter Boletina Feminista $\mathrm{La}$ Escoba. The goal of CIDEM's Observatorio Manuela: Violencia, Feminicidio y Mujeres en Riesgo (Manuela Observatory: Violence, Femicide and Women at Risk $)^{6}$ was to document primarily the killing of women, or femicides, in its archive but also other topics affecting women's lives (e.g. crime, legislation, law, judicial system, gender violence, women and crime, politics, citizen security, racism). I drew on the work carried out by the CIDEM activists and everyday encounters to develop my own researcher-activist role and understand such displays as the wrestling match. CIDEM carried out 'activist research practice' (Choudry 2013) and published studies ${ }^{7}$ regularly seeking to influence social policy and the law. CIDEM managed to modify the penal code to include femicide in 2013 after the adoption of Law 348. However, CIDEM would later close because of a lack of funding from international aid agencies affected by state policies.

Observatorio Manuela Manager Lourdes Peñaranda at one stage gifted me with a tote bag with the Bolivian flag that read: 'My body is mine. Not of the state, not of the church. Free people, secular states.' The CIDEM women applied a feminist universalist principle by which all women, despite their differences and place of origin, were partners in the fight against the patriarchy and so deserving of mutual support. 
Some of the CIDEM members outspokenly supported the anarchofeminism of Mujeres Creando (Women Creating), also a Bolivian feminist organisation. CIDEM women did not draw on the traditional figure of the Aymara self-sacrificing mother, perpetuating discrimination against women (Lazar 2002: 20). Many of the CIDEM staff had not yet had children, and their female subjectivity did not draw on an early motherhood model. None of the CIDEM staff I knew wore pollera, but they instead wore trousers, indicating their high level of education and cosmopolitan feminist activism. They nevertheless actively supported the cholitas, mostly in their work in El Alto, and the cholitas participated in CIDEM's public protests, thus maintaining Aymara women's experience at the center of CIDEM's feminist activism. This experience extended to popular images of violence. The wrestling match between the cholita and the colonel exemplified these spaces of popularising violence. I describe one of these matches as seen in the Ceja, El Alto, to later deconstruct its images.

\section{Performing anger and violence}

The wrestling match described earlier starts when a coronel enters the wrestling ring wearing a military suit and black leather boots, followed by the cholita wearing a purplish (not the same kind of purple of the feminist movement but close enough) and a blue blanket, fastened with a golden brooch embellished with stones that matched her bowler hat's larger brooch and earrings. In the wrestling bout, from the outset, the colonel is performing anger with the cholita because she gets public attention. The cholita salutes the public from outside the ring while the colonel observes the cholita from inside. The cholita goes out and down the ring to meet the public, and the colonel follows her. Behind her, he issues threats, punching her in the head while she engages with the public. When they both go back up into the ring, the cholita takes off her bowler hat, blanket and jewellery in preparation for the fight. Soon after, a referee starts the match. The cholita and colonel throw each other around the ring doing flips from the ropes until the cholita hits the colonel. However, she does not pin him down to the floor for a count of three, otherwise the fight would have ended barely minutes after starting. Subsequently, the colonel and the cholita go up in the ropes looking victorious and seeking public support. Then, the colonel hits the cholita in the mouth and head. She cleans blood from her lips with her pollera. The colonel grabs her from her back, holding her arms up. The referee 
intervenes, taking sides with the colonel, both men. Betraying any fairness, he kicks the cholita in the stomach.

The colonel then grabs her two long braids, echoing gendered forms of colonial control. I was told the cholitas' hairstyle came about from the Spanish colony, as this female hairstyle - two long braids - helped the colonisers physically control women's bodies by their braids. The colonel pushes the cholita to the floor. Again, he throws her against the ropes and the floor. The cholita, attacking, gets the colonel to the floor too. The referee unfairly mediates the fight again and hits the cholita. The colonel puts the cholita to the floor again and pushes her face towards what looks like dirty toilet paper on the wrestling ring floor. First, he pushes her head with his arms. Second, he pushes her head down by sitting with his backside on her head. The cholita resists touching the dirty tissues with her face. After this, and again, the referee hits the cholita in her face, and the colonel hits her in her head with a metal tray, which he later pushes into her face while she lies on the ring floor under his military boot.

While the cholita lies on the floor, the colonel goes outside the wrestling ring to get a metal wheelbarrow. He carries the cholita's body out of the ring and puts her inside the wheelbarrow outside the ring. Then, he carries her body in the wheelbarrow around the ring and in front of the public sitting outside a metal fence. The public shouts, supporting either the colonel or the cholita. The colonel then puts the woman on the floor by tilting the wheelbarrow. The woman lies on the floor for a while. Then, the colonel holds her up, grabbing her head and making her walk. Forcing her to regain 'consciousness', he beats her on the head with the metal tray again, and she falls to the floor grabbing her head near the protection fence. At this point, the cholita gathers strength, takes the metal tray from the colonel's hands and hits the colonel in the head. The colonel falls to the floor apparently unconscious. The cholita goes back to the ring and hits the referee with the metal tray too. After, she goes out the ring and takes the wheelbarrow to put the colonel inside it. The cholita transports him around outside the ring for the spectators to see. Finally, she drops the colonel on the floor before she leaves the ring. She retaliates by attacking the colonel with the same violence. The result of this 'gendered violence equalising act', due to the ordering of events, is that the cholita wins the fight. 


\section{Vigilant systems of urban security}

The wrestling match between the cholita and the colonel can be analysed at two different levels. First, this particular wrestling match symbolises the long-term tension between indigenous and colonial powers and legacies. In the wrestling match, the gendering of the Aymara culture is feminised in the figure of the cholita, bearing the essence of the indigenous Aymara group (Haynes 2015), while the state and its legal system is masculinised in the figure of the colonel and the corrupted referee, thus portraying two gendered moral sides (Haynes 2013: 436) alongside the gendering of legal powers. Both men, standing for the state police forces and the state justice system, beat the cholita up until she gains strength and puts down the colonel. Then, the referee does not attack her again. In so doing, one could argue the cholita metaphorically gains power over the moral and legal powers taken away from indigenous people during the colonial period. In the context of El Alto, where the wrestling match takes places, it refers to the political and legal powers of the city's most prominent indigenous group, the Aymara. The cholita wins the fight, so her power is gender-equal to the colonel in beating down another person but also more prominent. The colonel's body stays on the floor outside the wrestling ring and, the cholita, who has won, leaves the ring. Thus, the fight also tells a story of the history of the relationship between Bolivian indigenous cultures and the powers of colonisers. Several authors argue the figure of the cholita, or mujer de pollera, stands for the pueblo, the indigenous people (see De la Cadena 1995 for Peru; Lazar 2002 for Bolivia), and the women's pollera as a symbol of 'resistance' and commerce skills (Stephenson 1999).

Regarding the history of Bolivia and the indigenous Aymara political power, Aymaras, despite being 'beaten up' through centuries, remain in the triumphant figure of President Evo Morales, who is argued to be an 'icon of indigeneity' (Goldstein and Castro 2006: 383, cited in Haynes 2015). As this wrestling fight takes place in El Alto, it also indicates the tension in El Alto in dealing with urban violence between the prominent Aymara community justice system, known as justicia comunitaria (a term widely used in the news articles I rely on from 2009 and 2010; a term which came to be known as jurisdicción indigena originario campesina with the formulation of the Ley $N^{o} 073$ de Deslinde Jurisdiccional on the 29th of December 2010); and the state justice system embodied in the El Alto Fuerzas Especiales de Lucha Contra el Crimen (Special Forces to Fight Crime-FELCC). Implicitly, it gives voice to the Aymaran communities living in El Alto known as vecinos (neighbours) 
and their concern about their capacity or incapacity to provide citizen security, known as seguridad ciudadana, in the absence or presence of the state legal apparatus. This is embodied in the FELCC police presence in the streets, being the vecinos' legal powers limited by the state. In the wrestling match, the colonel is finally beaten down by the cholita, who stands for indigenous justice, so the Aymara's justicia comunitaria is not taken down or replaced by the state justice system, but its role in providing citizen security in this symbolic realm remains and prevails over state law.

\section{CIDEM's vigilant capacity}

Second, the wrestling spectacle was a visual cliché about men beating up women, particularly cholitas, reproduced in discourses held and information handouts delivered by women and feminist organisations such as CIDEM, and made available in mass media and popular culture. The wrestling show echoed other forms of 'mass media politics' such as the popular TV programme La Tribuna Libre del Pueblo, which ignited the later popular political party Conciencia de Patria (Conscience of Fatherland), bringing El Alto rural-urban Aymaran migrants' issues of concern to the fore. Discussions on sexual assaults on adults and children, missing people and physical fights were televised (Lazar 2002: 6), so El Alto was portrayed as a hostile urban environment versus the security of the countryside (18). Rather than giving a voice to the pueblo, as Tribuna Libre did (6), the mixed gendered wrestling match did not induce the public to take sides with the oppressed, the cholita. The wrestling spectacle indicated a social concern about El Alto not being safe for women who are vulnerable to men's attacks. Conversely, it also implied women's violent capacity to injure another human being.

In some of the newspaper articles archived by CIDEM, cholitas were also described as perpetrators of violence, not only as victims. For example, there were cases in which cholitas were members of organised criminal gangs. This ultimately referred to women's violent capacity, equal to men, to retaliate and to achieve justice. More broadly, in agreement with Haynes (2015), the wrestling cholita figure links the figure of the cholita with her feminine capacity of protest, which becomes visible in the protests of feminist women's organisations such as those organised by CIDEM. Further, the spectacle also pinpointed the limits of the 'vigilant' capacity of the FELCC and the vecinos 'vigilantism'. Vigilantism is a term that has been used to refer to justicia comunitaria and its charac- 
teristic form of justice: lynching or 'mob violence' (Goldstein 2003: 23), however many indigenous people reject the association between justicia comunitaria and lynching (Wemyss 2020, personal communication). The colonel beating a woman in the wrestling ring specifically stands for the faulty FELCC provision of citizen security to women. The show reproduces and normalises the image of a beaten woman against which women's and feminist organisations protest, an image of a social reality CIDEM seeks to eradicate by widening women's rights and legal protections. The image of the beaten or killed women is the women's image observed by CIDEM and other women's and feminist organisations. In so doing, the wrestlers participate in CIDEM's advocacy by proxy, observed through their 'vigilant' roles of documenting and making visible violence against women and femicides, returning us to the work of Observatorio Manuela.

\section{The femicide case of Manuela}

The watchdog Observatorio Manuela was named after an alteña, a Bolivian woman from El Alto, known as Manuela. Manuela was killed by a hitman her husband had paid following their marital separation. She had separated from her husband to stop marital violence. CIDEM noted in its newsletter that Manuela's husband had not 'accepted' or 'respected' Manuela's decision to break up with him. Further, CIDEM denounced that Manuela's homicide, a femicide, had gone unpunished. After four years of trial, Manuela's murderers were free on the streets because of the lack of criminal evidence and a gender-discriminatory legal system. The goal of the Observatorio Manuela was to document violence against women, femicides, and to pinpoint the limits of the law in prosecuting these crimes, many of which remained unpunished, lobbying for legal changes. ${ }^{8}$ According to data collected by the Observatorio Manuela between 2009 and 2013, there were 492 femicides in Bolivia (Marca Paco et al. 2015: 20).

Lourdes's office was decorated with puppet witches hanging from the ceiling that had been sent to CIDEM from across the world. ${ }^{9}$ The staff called themselves 'the CIDEM witches'. Its newsletter's name was La Escoba, meaning 'the broom', referring to the broom of a witch. The figure of the witch refers to a woman with powers who is not under the control of men, generally understood to be dangerous and with the capacity to unravel a social system. The 8 March 2010 issue of $L a$ Escoba, published on International Women's Day, contained the history 
of the Observatorio Manuela, including statistics on femicides, femicide cases extracted from national newspaper articles and related material, responding to the most important gendered social problem of femicide in Bolivia. G. J. Reyes Garcia (2018) has argued the topic of femicide was little known by the Bolivian attendees to the awareness-raising workshops delivered in La Paz, Cochabamba, Santa Cruz and Chuquisaca in 2010 and 2011 by two grassroots organisations. ${ }^{10}$ Furthermore, by 2012, some half the population consulted were unaware of the meaning of the term femicide.

CIDEM worked in partnership with twenty-two news agencies (Marca Paco et al. 2015: 43). This further relates to how the media has acknowledged Bolivian indigenous women's organisations as political subjects since the 1980s, following the fall of the 1970s military regimes and throughout the democratisation process, to become autonomous political subjects in the 1980s (Rousseau and Morales Hudon 2015: 48). ${ }^{11}$ Printed in $L a E s c o b a$ 's pages were cut-outs from newspaper articles on women's femicides. This was similar to the material we selected at CIDEM to compile the actual physical femicide archive. The articles narrated the stories of murdered women who had been killed out of the sight of witnesses. My own experience of walking through the vast spaces of El Alto neighbourhoods helped me understand the vulnerabilities El Alto women faced when transiting apparently deserted spaces or spaces that were still in the process of development and habitation. The lack of safety in such spaces and violence against women were documented through the CIDEM Observatorio Manuela archive.

CIDEM is 'vigilant' of women's killings, and equally, CIDEM is 'vigilant' of the state's and the vecinos' legal powers, which from CIDEM's perspective stand for the patriarchal system, submitting women to men (Zapana 2015), discriminating against women, culturally and legally, and creating a scenario in which women are beaten and killed. Having said this, CIDEM's 'vigilant' role, as other feminist women's organisations documenting and denouncing violence against women, arguably complements the vecinos' vigilant capacity in El Alto, where both the vecinos and the state police forces fail to be sufficiently vigilant to ensure citizen security. CIDEM as a 'vigilant figure' supports the vecinos' demands for higher state protection in El Alto. However, according to CIDEM's archive and journal articles, while the vecinos focus their efforts on the one hand on increasing FELCC presence in El Alto, and on the other on their justicia comunitaria being given equal legal value vis-à-vis the state justice system, as it was achieved with the 2009 Constitution, CIDEM demands legal changes to more severely punish 
femicides. Both strategies aim at deterring urban gendered crime, crime more broadly and femicides more specifically.

\section{Observatorio Manuela}

The CIDEM Observatorio Manuela archived printed and digital newspaper articles in which women, including cholitas, who actively participated in the national economy - running convenience stores, selling vegetables and other products in the El Alto and La Paz markets - and travelled across the country, were attacked by men who wanted to rob them, implicitly indicating indigenous women's high economic status. Like the cholita in the wrestling ring who took off her blanket, hat and jewellery to fight a man, women living in El Alto were disposed of their valuables: money, goods, mobile phones, gold jewellery or bags. Most of the robberies by men were described as murder attempts of their female victims. Women were choked to unconsciousness or strangled to death by men's bare hands but were also strangled with shoelaces or ropes. At times, these women were stabbed or shot. The newspaper El Alteño (2010a) reported a cholita running a convenience store had been strangled by a twenty-five-year-old man after she asked him to pay for alcoholic drinks he took from her shop. The man was a known vecino. The article explained the cholita's next-door vecinos listened to what happened but 'let the man go because they knew where he lived'. The next morning, all the vecinos gathered at this man's door, beat him and almost lynched him. Remaining 'sensible', the vecinos took the man to the El Alto FELCC instead of killing him, thus collaborating with the FELCC and restraining their indigenous legal powers in a dialogue with the state. The newspaper had a photo of the cholita, explaining how the man had tried to strangle her with his hands.

The newspaper El Extra (2009a) reported a teenager coming home from night school was robbed of her mobile phone and money by a man threatening her with a knife. When she started crying, he stabbed her in both breasts and she screamed. Hearing her scream, the vecinos 'trapped' the thief and took him to the sports pitch, a cemented and urbanised developed area, where the vecinos meet for political decisionmaking and legal matters. According to the report, the vecinos took the man's money and his clothes and beat him until the police intervened and they agreed to hand over the man to the state police. The newspaper El Extra (Nathaly 2010) reported a case with a different outcome: a mother and daughter who had taken a minibus on their way to sell 
chickens and mate in the Ceja had been chocked by men sitting in the back of the minibus until they lost consciousness. When the vecinos saw their unconscious bodies on the street, they took them to the hospital and saved their lives. A photo of a cholita lying on a bed and receiving oxygen from a doctor accompanied the article. In this case, the vecinos did not witness what happened or were able to 'capture' the thieves. This indicates the limits of the 'vigilant' role of the vecinos in non-observable spaces where the state cannot watch over either. A similar article in El Alteño (2010b) was accompanied with a photo of a cholita with visible strangulation bruises on her neck after she had been attacked in a minibus.

To avoid the vecinos reprisal resulting from witnessing a crime, many of the criminal acts are committed in vehicles, taxis, radio taxis or minibuses, so criminals can hide their identities more easily. This relates to the article by Teresa Lanza (2010) in La Razón on 'violence on wheels'; 'vehicles of death, rape, robbery'; and 'vehicles of an express kidnapping'. La Razón (2009b) showed the image of three criminals tied, bleeding and burned. The identity of the vecinos who lynched them, up to a hundred, remained unknown because the vecinos had a 'silent pact', or codigo del silencio, according to the newspaper. The newspaper articles claim that if the vecinos witness a crime, they will act. They will 'trap', 'detain' and 'capture' the thieves and criminals, referred to in Spanish as anti-sociales, agents who go against sociality. Sociality refers to 'living well' (el vivir bien), a materially sufficient, sustainable, happy, moral way of life. Criminals are also referred to as personas de mal vivir, or people who do not live well, so that vivir bien is dependent on citizen security, as argued by Lanza (2010).

The Observatorio Manuela's archive contained newspaper articles on how vecinos who had witnessed a crime applied justice by beating or lynching to death or 'reducing' the criminals, meaning forcing criminals to abide to the community's moral laws. Many of the articles about lynching and femicides were written by anonymous journalists, just as a lynching had been carried out by 'no one'. In 2009 and 2010, the new Citizen Security Law (Ley de Seguridad Ciudadana) was under discussion and approval in the senate. The newspaper's articles and photos, criminal puppets in the streets and the very 'neighbours' lynching - different forms of justicia comunitaria - showed the limit of the state security forces, particularly the FELCC, in granting urban security and also the limits of the state security force's laws to prevail over the justicia comunitaria. La Razón (2009a) claimed the vecinos resort to 'desperate measures' to respond to urban insecurity and the lack of police presence, along- 
side other everyday security practices such as daily and nightly neighbourhood vigilance, whistleblowing, metal fences blocking streets or private security. ${ }^{12}$ The article was accompanied with a picture of graffiti on the wall of a building reading, 'The thief will be lynched'.

Before the Law $N^{\circ} 264$ Citizen Security was passed on the 31st of July 2012- El Alteño (2010c), quoted the FELCC colonel Wilson Ramirez calling the vecinos to work together with the state to grant citizen security as a shared reponsibility. The collaboration between the two legal orders orchestrated in this way pushed a citizen security agenda in which security provision remained in control of the state, criminalising the vecinos' lynching. This was even when acknowledging the vecinos' vigilantism was necessary to ensure citizen security. Goldstein argues vigilantism bears a contradiction: it embraces and reaffirms the state legal system's commitment to protecting communities but also rejects it because justice can be achieved besides the state legal system (2003: 25). ${ }^{13}$ These accounts of lynching, changes to the law and the role of the communities through the actions of vecinos to act against criminals are notably absent when dealing with femicides.

\section{Femicides}

The newspaper articles on femicides archived in Observatorio Manuela for 2009 and 2010 tell a different story about how a criminal act against women is handled in El Alto particularly. The most remarkable issue coming up from the journalistic narratives about the killing of women is that this gendered crime goes unseen by the vecinos and the FELCC. The vecinos do not call the FELCC to take away a criminal or to repress a lynching. The vecinos call the El Alto FELCC or the helplines of the Patrulla de Auxilio Ciudadano (Citizen Assistance Patrol) or Radio Patrullas 110 (Radio Patrol 110) to take a dead woman's body away from their communities. According to the journalistic reports, the women are killed elsewhere, not in the vecinos' communities where the women's dead bodies are found. Thus, these dead women have been killed away from the very women's community of origin and out of the vecinos' vigilant gaze. Goldstein has argued women living within communities are watched over for their protection and women's movements are severely controlled, fearing going out at night, transiting particular neighbourhoods or talking to strangers. Further, strangers entering a community are regarded with the suspicion that they might be a housebreaker, child molester or rapist (2010: 497). 
The women killed were 'outsiders' to the communities, and the women's dead bodies were dumped like rubbish in the vecinos' lands, sometimes in rubbish bags, in their neighbourhood streets, rivers or dumpsites, from a vehicle. When in the wrestling match the colonel pushes the cholita against dirty toilet tissues, this echoes the dumping of dead women's bodies in dumpsites. El Alteño (2009a) included a photo of a murdered woman found in a dumpsite in El Alto, her body and clothes blackened and burned, as it was inspected by an El Alto FELCC police officer under the vecinos' watch. Before seeing the body, the vecinos had smelled the woman's dead body rotting. Some other vecinos said they saw a van dumping a black rubbish bag on the dumpsite and lighting it the day before, but they had not guessed it was a woman's dead body. According to the investigation, the woman had been killed in a different part of the city, and the cause of death was a head contusion. Murderers killing by hitting the head of a person was a popular practice in Bolivia. The murderers had 'cleared up' all evidence, which was referred to as 'a cleaning job' (un trabajo de limpieza). This expression is similarly used by yatiris, Aymara healers, to refer to the rituals they practice to clear up a curse or a love spell, for instance; this is cleaning or removing the effect one person's powers has had over another. According to the journalistic narratives, the vecinos do not witness the crime and thus are unable to protect the women, intervene at the moment a gendered crime is being committed and apply their justicia comunitaria. The vecinos' lynching justice depends on witnessing an injustice, so it could be referred to as 'a justice of witnessing'.

The newspapers' femicide articles were accompanied with forensic photographs: women's bodies on the dusty stone floors of barely developed urban areas of El Alto while being examined by El Alto FELCC representatives under the vecinos' watch; women's bodies inside FELCC patrol vehicles, sometimes with visible cuts in their bodies and blood; and sometimes women's bodies removed from the place they had been found to the FELCC vehicles or the morgue in wheelbarrows. El Alteño (2009c) reported a subject with her face cut and unrecognisable had been found in El Alto. While her identity was unknown, her clothing showed she was a cholita. The article was accompanied with a photo of the cholita upside down inside a wheelbarrow as the body was transported to an El Alto FELCC vehicle. Some of the murdered cholitas were missing their blankets, pollera, hats or personal documents. Such was the case documented by El Extra (Tancara 2009) when a cholita was murdered when she was returning home after a party. She was also missing her blanket and bowler hat. This relates to the performance in the wrestling 
ring where the cholita disposes herself of these personal accessories of high-status Aymara female identity before she started the fight with the colonel. Similarly, there is a relation between the performance in the ring with the journalistic images of women's dead bodies being transported in wheelbarrows, from the place where they were found in the other people's communities, to the inside of police cars or the morgue. At the wrestling show, the colonel uses the wheelbarrow to transport the cholita around the ring after knocking her down. Thus, the wrestling match is echoing how women's dead bodies are exposed through the media and further exposed to the public by feminist women's organisations such as CIDEM, in an attempt to raise a concern about femicides to change the gender of the law.

Many of the women reported killed in the newspapers had been murdered by a person who owed them money. El Extra (2009b) reported the murderer of a woman and her child found dead on 5 January was a man the victim visited on 3 January to collect a loan of $\$ 15,000$ when delivering four laptops. The article also said the man, alledged perpetrator, who had been called to appear in court had run away from the place immediately after, afraid the woman's relatives now knew his identity and would take justice 'in their own hands'. This is applying justicia comunitaria rather than following the state law. Many of the murdered women were older than thirty and were successful women, whose social power could be eliminated or 'cleaned away' only by choking their social voice or by stopping their thinking by targeting their heads. Sometimes a woman and her infant child, an extension of the woman's persona, would be killed at the same time. The murderers were sometimes thieves, others business partners, partners, ex-partners or ex-partners' hitmen; in other words, the profile of these male perpetrators was wide ranging. Only in a minority of cases was it reported that women had run away to their neighbours for protection before they were killed, and it was not recorded whether, before the murder, women had been in contact with women's rights organisations such as CIDEM seeking advocacy.

Most of the women killed had been strangled with shoelaces, ropes, cables, men's ties or the woman's long braids or blankets. The women's throats were cut, their heads targeted with blunt force trauma, or they were shot, stabbed multiple times and/or burned. In light of this forensic evidence, there were some similarities between the killing techniques of the femicides and lynching: head trauma, beating and burning. Women were disfigured, and sometimes their fingerprints were sliced out. The criminals burned the women's bodies attempting 
to erase the woman's identity altogether, her sociality, just as the vecinos' lynching attempted to do the same to 'reduce' the criminals. An extreme case was reported by El Extra (Nathaly 2009) in which a young man beheaded his girlfriend after having intercourse with her in an hourly rented hostel in El Alto. Hostels were referred to as 'death hostels' (alojamientos de la muerte). When the hostel's manager, in his vigilant role, stopped the man and asked where the woman was who had arrived at the hostel with him, suspecting he might have killed her, such was the popularity of the practice, the man tried to run away with the woman's head in a box. The hostel manager, however, managed to restrain him until the police were called and arrived at the hostel.

While some of the femicides' suspected motive was robbery, the newspaper articles also considered these murders 'crimes of passion', as was the case of the murder of a twenty-eight-year-old woman and her child of six by her husband found in the industrial zone Franca in district 3 of El Alto, according to El Alteño (2009b). In legal terms, these murders were considered 'crimes of passion' when the women's killings were not considered homicides, and judges gave the murderers' minimal custodial sentences. Nevertheless, Reyes Garcia (2018), researching sentences given before and after Law 348, has argued similarly when women and men killed another person, they were given a maximum sentence of thirty years, upon the conditions of the availability of witnesses and if the female victim's relatives exercised pressure on the judge to give a long sentence to the murderer, and/or the judge wanted to avoid accusations of corruption. A lesser sentence would indicate the judge had been bribed by the murderer's family. Regardless, CIDEM pursued changes to the penal code to typify women's murders as gender murders: to ensure femicides were punished similarly to men's homicides and to acknowledge gendered crime and discrimination within the penal code. The connection between the cholita and colonel's wrestling match with CIDEM's archived images appeared as happenstance but is related to the overall effect and images of violence.

\section{The gender of Bolivian women's organisations}

Despite CIDEM's legal success in 2013, modifying the penal code to include femicide with the articles 83 and 84 of the Law 348, it was closed in 2016. This returns us to how CIDEM's vigilant, visualisation and awareness-raising work related to violence against women. Karin Monasterios (2007) argues there are three types of Bolivian women's 
movements 'ideologically polarized' in the 1990s: liberal, NGO-based 'gender technocracy' and anarcho-feminism. In her view, CIDEM falls within the category of gender technocracy because focusing on one NGO's gender issues upholds an anti-patriarchal position and depends on international cooperation funds. Monasterios argues organisations such as CIDEM and the Centro de Promoción de la Mujer Gregoria Apaza (Gregoria Apaza Women's Promotion Centre) act as a 'state regulating body' with a 'quasi-public-sector role', and in so doing, they have been 'co-opted' by the neoliberal state following UN conventions, and they downplay grassroots women's needs and consciousness. Stéphanie Rousseau and Anahi Morales Hudon (2015: 55) argue against clear-cut boundaries of women's organisations and posit that beginning with Morales's 2005 election, middle-class urban feminist and grassroots indigenous women have developed inter-organisational collaboration networks and joint platforms on women's rights. Despite dissenting voices, Bolivian indigenous women's political subjectivity results mainly from women's own agency and their close links to male-dominated mass organisations, such as the case for the National Confederation of Original Indigenous Peasant Women of Bolivia or the National Confederation of Indigenous Women of Bolivia (Rousseau and Morales Hudon 2015: 50; 55). Lacking male alliances might be one reason CIDEM closed down in 2016 after successfully getting Law 348 passed on 9 March 2013 to modify the penal code and criminalise femicides. CIDEM lacked funding provision from development agencies, whose work was watched and limited by the state national policies, or funding from the state (Mendoza 2016).

CIDEM's (2015) comprehensive publication on its 'integral strategy' from 2008 to 2013 to change the national legislation on femicides reported its involvement in Morales's Asamblea Nacional Constituyente to modify the constitution in 2009, ensuring women's right to live free from violence. Law 348 was preceded by CIDEM's critical consideration of Law 1674, which regarded exclusively three types of gender violence (physical, sexual and emotional), was limited to the domestic space and specific perpetrators (husband, father or brother) and prioritised reconciliation between the victim and the aggressor. CIDEM's femicide 'integral strategy' illustrated CIDEM linkages with civil society, NGOs, state representatives, journalists, politicians and the relatives of women whose murder was categorised as femicide. In the report, a graphic showed CIDEM's body connections with other agents as octopus arms: the state; the grassroots assemblies (asambleistas); the Defensoria del Pueblo ('a government funded legal ombudsmen', see Wemyss 2016); 
International Cooperation Agencies; the Comité Impulsor de la Agenda Legislativa Desde las Mujeres (Women Promoting Committee of the Legislative Agenda); the coalition EPU-CEDAW; other networks such as the Red de Prevención y Atención de la Violencia Intrafamiliar de El Alto (Network of Prevention and Attention to Domestic Violence in El Alto). CIDEM also collaborated with the following public educational campaigns against violence: Campaña por el Derecho a la Education (Campaign for the Right to Education) and Alianzas, Campañas Bolivia ;Ya! Libre de Violencia (Bolivia Free of Violence, Now!). CIDEM's social engagement to advocate for change to the gender of the law was thus multi-sectorial, including grassroots organisations, the state and international agencies. CIDEM reformulated its movement boundaries (Rousseau and Morales Hudon 2015: 43) beyond its 'gender technocracy' profile. CIDEM's closure was 'announced' by the digital newspaper Página Siete: Diario Nacional Independiente (Mendoza 2016) on Facebook. The article was accompanied by a photo of the Centre Adela Zamudio office space where CIDEM's femicide archive was before stored in shelves, but now its lever arch files appeared on the floor. Next to them were an actual broom, a dustpan and a plastic rubbish bin bag, cleaning the mess left behind by CIDEM's archival centre. The journalist noted CIDEM's once-hanging witches had also been collected into plastic bin bags, just as the dead bodies of women were found in El Alto. A symbolic shutting down of CIDEM's independent feminist critique of the masculine order seeking a more equal society. This might result because CIDEM's work is not complementary to the men's work; rather it opposes the male order, thus disturbing Bolivian gender complementarity (Harris 1980).

\section{Conclusion}

This article argues visual images, such as the one here presented of the cholita and colonel in the wrestling match, represent past, present and future public debate on violence against women, legal change, as well as social rights movement networks linking the state, civil society, NGOs, international aid agencies, local police forces and customary legal agents. This popular image is linked to other images of violence against women available in the national mass media and made further available by CIDEM. This article has indicated the complementary, vigilant role of the vecinos, if insufficiently, acting alongside the state while focusing on the feminist women's organisation CIDEM in its efforts to ensure citizen security, particularly women's security. CIDEM's vigilant 
role over women's safety posit justice cannot be achieved apart or in opposition to state law, thus aligning its vigilant role over the international human rights agenda and condemning de facto lynching as a human rights violation (Goldstein 2003: 32). In CIDEM's office, the hanging witches symbolically replace the vigilant role of the vecinos' street hanging criminal puppets with anti-patriarchal and legalistic human rights vigilance. Furthermore, as described in the newspaper articles, which included interviews with vecinos, the identity of a man who kills a woman is most often not in the first instance known, so direct retribution following the witnessing of this type of crime is rarely possible. Thus, the murdered women's families' justice for the out-of-sight femicides depends more greatly on the forensic examinations offered by the state legal system and the criminal being found and sentenced with the maximum penalty for homicide, thirty years, which is equivalent to a life punishment of ostracism or 'social reductionism' offered by the lynching. And so, these major crimes are out of the vecinos jurisdiction.

This, however, depends on the police singling out the criminal or criminals to punish and not abandon the prosecution (Goldstein 2003: 32). Thus, the police collaborating with the women's groups who call for the criminalization of the femicides bear, I would argue, a possible tension, as it entails the police collaborating with a group of women who critically examine the police's work, as they critically observe any other member party of the state judiciary system failing in fair arbitrage of state law. A female gendering of the law requires, put simply, that the colonel and the referee in the wrestling bout, standing for the FELCC, rather than betraying fair arbitrage by aligning themselves with the man who assaults a woman, protect her and abide by the law. In the wrestling match, however, the cholita is not aided by the referee, standing for the state legal system; rather, she takes 'justice in her hands', rebalancing the power of the genders to apply justice, which ultimately refers to the idea of security and legal equality for the genders. In the wrestling match analysed here, there is thus an implicit critique of the power of the law to grant equal legal justice, even when a new gender of the law seems to be the solution for gender-discriminatory legal systems and femicides. This is a limit to CIDEM's femicide strategy. CIDEM's vigilant role pertains to the liberal democratic paradigm, in which citizens' rights to state protection through laws and welfare policies, depends on making visible 'life at risk' (Zeiderman 2013: 73), as it is in Colombia and more broadly in Latin America, where we found participation in the Ni Una Menos (No One Less) movement against femicide. 


\section{Acknowledgements}

I would like to thank CIDEM for letting me volunteer at the Observatorio Manuela compiling the femicide archive during my stay in Bolivia in 2010 and for inviting me to partake in its activist work. I would like to thank Lourdes Peñaranda, director of the Documental Centre Adela Zamudio; Magaly Achá Tarqui, one of CIDEM's lawyers; and Jeanethe Parisaca Mancilla, a sociologist working at CIDEM's Observatorio Manuela's archive as a technical staff - first for their friendship and second for letting me take a sample of the Observatorio Manuela's archive for research purposes. I would like also to thank Dr Martyn J. Wemyss for sharing with me a part of his fieldwork in El Alto, La Paz and the Lago Titikaka communities and for his comments on this article.

Xandra Miguel-Lorenzo recently completed her PhD at the London School of Economics. Her research examines gender violence in postconflict Solomon Islands. Email: xandramilo@gmail.com

\section{Notes}

1. El Alto has been a city in its own right since 1985, originating in 1930 around La Paz's airport.

2. This is a city with a majoritarian composition of rural-urban migrants of Aymaran indigenous ethnicity, mostly second and third generations (Lazar 2002). Aymaran men and women are referred to as cholo or chola. While these terms indicate essentially lower-class indigeneity, the term cholita carries positive connotations about traditional attire, marital status and commercial skills (see Albro 2000; Buechler and Buechler 1996, cited in Lazar 2002; Stephenson 1999).

3. CIDEM was founded in 1983 by exiled feminists returning to Bolivia following the dictatorship of Luis Garcia Meza. One of its three founders, Sonia Montaño, received $\$ 10,000$ for her return while in exile in Holland and, with two other exiled female feminist returnees, founded CIDEM (Mendoza 2016). This organisation had its main office in La Paz and a satellite office in El Alto.

4. Femicide is understood as the intentional killing of women/girls because their gender is female, according to CIDEM's reference to Diana Russell's (1976) work 'Crimes against women: international tribunal proceedings' (Marca Paco et al.'s 2015: 40). The Spanish term for femicide in Bolivia is feminicidio rather than femicidio. CIDEM see femicide as an unpardonable crime to be punished with thirty years' imprisonment.

5. I participated in CIDEM's public demonstrations against urban rapes. I attended one of CIDEM's meetings with Bolivian local authorities and mass media representatives. I helped deliver a workshop given to El Alto's women, including 
cholitas, on gender violence and women's rights according to Bolivia's civil code. In La Paz, I attended CIDEM's handover of their study on El Alto masculinities and an educational resource pack to prevent domestic violence in schools at the Ministry of Education.

6. The Observatorio Manuela was preceded by CIDEM's 2002 Sistema de Información para la Vigilancia Ciudadana desde una Perspectiva de Género (Information System for Citizen Vigilance from a Gender Perspective), which published all the women's gender violence police reports, gender equality statistics in the fields of education, health or political representation, for instance, and from 2004, all the femicides as recorded by the police homicide division. Another women's organisation noting the cases of femicide was the Centro de Promoción de la Mujer Gregoria Apaza, which in 2002 claimed poorly supported cases of gender violence resulted in femicide and that the legal system treated femicides discriminatorily and murderers enjoyed impunity (Reyes Garcia 2018). The NGO Colectivo Rebeldia (Rebel Collective) from 2000 to 2003 documented forty-nine femicide cases by intimate partners (Marca Paco et al. 2015: 44).

7. An example employed in this text is Marca Paco et al.'s (2015) report on the organisation's 2008-2013 'integral strategy' on its femicide campaign. Considering the case of the British women's organisation Southall Black Sisters, Rahila Gupta (2014) notes documentation of the organisation's activity serves to prove its social function (cited in Choudry 2013: 134).

8. The publication of La Escoba by CIDEM was funded with the support of the Spanish Ministry of Equality and the Spanish research centre on violence against women Comisión para la Investigación de Malos Tratos a Mujeres (Commission for the Investigation of Bad Treatment of Women).

9. Lourdes's office was inside the information centre Adela Zamudio, which included the archival material of the Observatorio Manuela, a feminist library, a research space and computers connected to the internet available for women to use free of charge. Lourdes also organised the PhD women writers' seminar series. I sent a puppet witch to CIDEM for Lourdes's office from Spain upon my return to Europe.

10. The workshops were delivered by the Red Nacional de Trabajadoras/es de la Información y la Comunicación and the Centro de Desarrollo Integral de la Mujer Aymara Amuyt'a.

11. Mass media plays a crucial role in supporting civil society's human rights movements in Latin America (Adelman and Correa de Azevedo 2012) and political subjectivity.

12. Goldstein argues lynching in Cochabamba, Bolivia, are considered expressions of rage and despair, responding to both crime and inequality at the political and economic level, as well as the state's neglect of communities' rights to justice and security (2005: 391), generating an 'ontological insecurity' and a shared sense that the 'judicial system is non-existent' in Bolivia (398).

13. This is jurisdicion indigena originaria campesina and the jurisdicion ordinaria $y$ la jurisdiction agroambiental. 


\section{References}

Adelman, M. and M. Correa de Azevedo (2012), 'Families, gender relations and social change in Brazil: Practices, discourse, policy', Journal of Child and Family Studies 21, no. 1: 65-74.

Albro, R. (2000), 'The populist chola: Cultural mediation and the political imagination in Quilllacollo, Bolivia', The Journal of Latin American Anthropology 5, no. 2: 30-88.

Butler, J. (1999), Gender Trouble: Feminism and the Subversion of Identity (London: Routledge).

Choudry, A. (2013), 'Activist research practice: Exploring research and knowledge production for social action', Socialist Studies / Études socialistes 9, no. 1: 128-151.

De la Cadena, M. (1995), 'Women are more "Indian": Ethnicity and gender in a community near Cuzco', in B. Larson and O. Harris (eds), Ethnicity, Markets, and Migration in the Andes (Durham, NC: Duke University Press), 329-348.

El Alteño (2009a), 'Asesinada y quemada: Fue botada el sábado en la madrugada' [Murdered and killed: She was dumped on Saturday at sunrise], 13 January.

El Alteño (2009b), 'Asesinados sin piedad: Tenian golpes en la cabeza y moretones' [Murdered without piety: They had contusions and bruises on the head], 6 January.

El Alteño (2009c), 'Cara cortada: Sujeto muere en la Ceja' [Cut face: Subject dies in La Ceja], 21 October.

El Alteño (2010a), 'Casi mata a una mujer por llevarse bebidas gratis' [He almost kill a woman to get free drinks], 3 May.

El Alteño (2010b), 'Peligro en minibus: Una banda opera en la madrugada' [Danger in the minibus: A gang operates at sunrise], 21 April.

El Alteño (2010c), 'En El Alto. Policías y vecinos contra la inseguridad ciudadana' [In El Alto. Police and neighbours against citizen insecurity], 25 August.

El Extra (2009a), 'Apuñalan en los senos a una quinceañera' [A teenager is stabbed in her breasts], 31 July.

El Extra (2009b), 'Hallan al asesino de una mujer y su niño' [Murderer of woman and child found], 11 January.

Goldstein, D. M. (2003), “'In our own hands": Lynching, justice, and the law in Bolivia', American Ethnologist 30, no. 1: 22-43.

Goldstein, D. M. (2005), 'Flexible justice: Neoliberal violence and 'self-help' security in Bolivia', Critique of Anthropology 25, no. 4: 389-411.

Goldstein, D. M. and F. W. Castro (2006) ‘Creative Violence: How Marginal People Make News in Bolivia', Journal of Latin American Anthropology 11, no. 2: 380-407.

Harris, O. (1980) 'The power of signs: gender, culture, and the wild in the Bolivian Andes', in C. P. MacCormack and M. Strathern (eds), Nature, Culture and Gender (Cambridge: Cambridge University Press), 70-94.

Haynes, N. (2013) 'Global cholas: Reworking tradition and modernity in Bolivian Lucha Libre', Journal of Latin American and Caribbean Anthropology 18, no. 3: 432-446.

Haynes, N. (2015) 'UnBoliviable bouts: Gender and essentialisation of Bolivia's cholitas luchadoras', in C. R. Matthews and A. Channon (eds), Global Sports on Women in Combat Sports (London: Palgrave Macmillan), 267-283. 
La Razón (2009a) 'Los vecinos asumen medidas desesperadas por la inseguridad' [The neighbours use desperate measures due to the insecurity], 15 June.

La Razón (2009b) ‘Vecinos de El Alto linchan a un ladrón y eluden a la policia' [El Alto neighbours lynch a thief and evade the police], 16 September.

Lanza, T. (2010) ‘Inseguridad ciudadana y género' [Citizen insecurity and gender], La Razón, 29 July.

Lazar, S. (2002) The 'politics of everyday': populism, gender and the media in La Paz and El Alto, Bolivia. Goldsmiths Anthropology Research Papers. London: Goldsmiths College, University of London. 1-33.

Madison Soyini, D. (2010), Acts of Activism: Human Rights as Radical PerformanceTheatre and Performance Theory (Cambridge: Cambridge University Press).

Marca Paco, M., G. Tapia Torrez, L. Peñaranda Morante and M. T. Guisbert Benavides (2015), El CIDEM y sus aportaciones para incorporar el feminicidio como delito en la normative national (La Paz: CIDEM).

Mendoza, S. (2016), 'Tras 32 años, el CIDEM Cierra su ayuda a las victimas de violencia', Página Siete: Diario Nacional Independiente, 14 February, https://www. páginasiete.bo/seguridad/2016/2/14/tras-anos-cidem-cierra-ayuda-victimas -violencia-86657.html.

Monasterios, K. (2007) 'Bolivian women's organisations in the MAS era', NACLA, 4 September, https://nacla.org/news/bolivian-women's-organizations-mas-era.

Nathaly, N. (2009) ‘Decapita a su novia y trata de huir con la cabeza' [Man beheades his girlfriend and tries to run away with her head], El Extra, 24 December.

Nathaly, N. (2010) 'Atracan a madre he hija dentro de un minibús' [Mother and daughter are assaulted within a minibus], El Extra, 6 February.

Reyes Garcia, G. J. (2018), 'Murder or femicide? Case studies in the department of La Paz', Temas Sociales 43.

Rousseau, S. and A. Morales Hudon (2015), 'Paths towards Autonomy in Indigenous Women's movements: Mexico, Peru, Bolivia', Journal of Latin America Studies 48, no. 1: 33-60.

Russell, Diana E.H. (1976), Crimes against women: proceedings of the international tribunal (Millbrae, Calif: Les Femmes Pub).

Stephenson, M. (1999), Gender and Modernity in Andean Bolivia (Austin: University of Texas Press).

Strathern, M. (1992), 'The Decomposition of an Event', Cultural Anthropology 7, no. 2: 244-254.

Tancara, M. (2009) 'Asesinan a mujer the pollera que se recogia de una fiesta' [Woman of pollera is killed returning from a party], El Extra, 23 November.

Zapana, V. (2015) ‘CIDEM: La mujer boliviana cade vez es menos sumisa y sometida’ [CIDEM: Bolivian women are less submissive and subdued], Página Siete: Diario Nacional Independiente, 9 October, https://www.paginasiete.bo/sociedad/ 2015/10/10/cidem-mujer-boliviana-cada-menos-sumisa-sometida-73001.html.

Wemyss, M. (2016), Human Rights and Legal Subjectivity in Highland Bolivia. Ph.D. thesis, Department of Anthropology, London School of Economics.

Zeiderman, A. (2013), 'Living dangerously: Biopolitics and urban citizenship in Bogota, Colombia', American Ethnologist: Journal of the American Ethnological Society 40, no. 1: 71-87. 